\title{
Cytopathic effects of Helicobacter pylori on cultured mammalian cells
}

\author{
H. KONISHI, M. ISHIBASHI*, M. G. MORSHED and T. NAKAZAWA
}

Department of Microbiology, Yamaguchi University School of Medicine and *School of Allied Health Science, Yamaguchi University, 1144 Kogushi, Ube, Yamaguchi 755, Japan

\begin{abstract}
Summary. Cytopathic effects of broth-culture filtrates from eight clinical isolates and one reference strain of Helicobacter pylori on three cultured mammalian cell lines were investigated. All the strains, including NCTC 11637, produced cytotoxic factors that caused intracellular vacuolation on these cell lines. AGS and Sf1Ep cells were more sensitive than HEp-2 cells. To examine the role of urease in the cytotoxic effect, a urease-negative mutant was produced. Filtrates from both wild-type and mutant strains produced similar vacuolation on Sf1Ep cells in the absence of urea, suggesting that $H$. pylori produces a cytotoxic substance other than urease. In contrast, ammonia alone, or jack bean urease with urea, also induced rounding and detachment of SflEp cells, whereas ammonium salts induced the production of small vacuoles. The combination of the broth filtrate of the wild-type strain and urea induced vacuolation followed by rounding and detachment of SflEp cells. Evidence is presented that the latter changes are due to ammonia produced during incubation. Nevertheless, the amounts produced were less than that needed to induce cytopathic effects by itself. These results suggest that the cytotoxic substance induces intracellular vacuolation, and that the vacuolated cells are more susceptible to killing by ammonia. Thus both the cytotoxic substance and urease may contribute to the lethal cytotoxicity of $H$. pylori in vitro.
\end{abstract}

\section{Introduction}

Helicobacter pylori (formerly Campylobacter pylori $^{1}$ is an aetiological agent of active chronic gastritis and a possible contributor to peptic ulceration. ${ }^{2-6}$ Although intracellular vacuolation has been observed by electronmicroscopy in gastric epithelial cells from patients with chronic gastritis, ${ }^{7,8}$ the mechanism by which this damage is produced is still unclear. Hupertz et al. ${ }^{9}$ demonstrated that the lysates from $H$. pylori were cytotoxic for Chinese hamster ovary cells and also lethal for mice after intra-peritoneal injection. Leunk and co-workers ${ }^{10.11}$ reported that $55 \%$ of isolates of $H$. pylori tested produced cytotoxins that induced non-lethal cytopathic effects (CPEs) in vitro in seven of nine mammalian cell lines, and suggested that the cytotoxin was produced in vivo. Figura et al. ${ }^{12}$ demonstrated that cytotoxin-producing $H$. pylori strains were isolated more frequently from patients with peptic ulcer disease than from patients with chronic gastritis only. In addition, Cover et al. ${ }^{13}$ reported that broth-culture supernates containing antigenic 128- and 82-kDa proteins induced vacuolation in HeLa cells. In contrast, Barer et al. ${ }^{14}$ and others ${ }^{15-17}$ have suggested that the urease activity of $H$. pylori is responsible for CPEs. To clarify the roles of cytotoxins and urease in CPEs in vitro, we examined "wild-type" $H$. pylori strains and a urease-negative mutant of one of these strains.

\section{Materials and methods}

\section{Bacterial strains}

Ten strains of $H$. pylori were used in this study. Reference strain NCTC $11637^{1}$ was obtained from Dr Inoue, Department of Internal Medicine 4, Hyogo College of Medicine, Nishinomiya, Japan. Eight strains were isolated from antral biopsy specimens from patients with chronic gastritis or gastric ulcer, or both, in the First Department of Internal Medicine, Yamaguchi University School of Medicine, Ube, Japan. ${ }^{18}$ A urease-negative mutant, CPY4111, was obtained from one of these, strain CPY4110, by exposure to $\mathrm{N}$-methyl- $\mathrm{N}^{\prime}$-nitro- $\mathrm{N}$-nitrosoguanidine (NTG; see below).

\section{Cultivation of bacteria}

Cells grown on Brucella Agar (BBL, Cockeysville, MD, USA) containing fetal calf serum (FCS; Flow Laboratories, Irvine, Scotland) $5 \%$ at $37^{\circ} \mathrm{C}$ for 2 days 
in a micro-aerophilic atmosphere $\left(\mathrm{O}_{2} 5 \%, \mathrm{CO}_{2} 10 \%\right.$, $\mathrm{N}_{2} 85 \%$ ), were transferred into Brucella Broth (BBL) containing FCS $10 \%$ and yeast extract (Difco, Detroit, USA) $1.2 \%$ (FCS-YB broth) and incubated for 2 days with shaking under the same conditions on a rotary shaker. Cultures were harvested by centrifugation and broth-culture filtrates (broth filtrates) were obtained from culture supernates by passing through a $0 \cdot 22-\mu \mathrm{m}$ membrane filter.

\section{Isolation of urease-negative mutants}

The cells of strain CPY 4110 cultivated in $30 \mathrm{ml}$ of FCS-YB broth described above, were harvested by centrifugation, washed once with $0.1 \mathrm{M}$ citrate buffer (pH 5.0), and suspended in $2 \mathrm{ml}$ of the same buffer. NTG was added at final concentrations of $0.02,0.04$ or $0.08 \mathrm{mg} / \mathrm{ml}$, followed by incubation at $28^{\circ} \mathrm{C}$ for $90 \mathrm{~min}$ without shaking. The cells were washed twice in M9 medium $^{19}$ and spread on TEP Agar plates (Eiken, Tokyo, Japan), which were incubated at $37^{\circ} \mathrm{C}$ for 4 days under the micro-aerophilic conditions. Approximately $0.4,0.15$ and $0.1 \%$ of the cells remained viable after treatment with $0.02,0.04$ and $0.08 \mathrm{mg} / \mathrm{ml}$, respectively. Each colony on the plates was transferred into FCS-YB broth in 96-well microtitration plates (Falcon, Lincoln Park, USA) and incubated under the same conditions as above. To screen for urease-negative mutants, the following two procedures were used. (i) Cells grown in wells in microtitration plates were transferred on to TEP agar plates, and incubated micro-aerophilically at $37^{\circ} \mathrm{C}$ for 3 days. They were then covered with a sheet of filter paper (Whatman 3MM) dipped in urea-medium (yeast extract $0.1 \mathrm{~g} / \mathrm{L}$; potassium dihydrogen phosphate, anhydrous $9.1 \mathrm{~g} / \mathrm{L}$; disodium hydrogen phosphate, anhydrous $9.5 \mathrm{~g} / \mathrm{L}$; urea $20.0 \mathrm{~g} / \mathrm{L}$; phenol red, $0.01 \mathrm{~g} / \mathrm{L}$ ). (ii) Cells grown in wells were transferred on to Brucella Agar plates containing horse serum (Handaibiken, Osaka, Japan) $5 \%$ and incubated microaerophilically at $37^{\circ} \mathrm{C}$. After 3 days, the plates were overlaid with $2 \%$ urea-agar. The colonies which did not show colour within $5 \mathrm{~min}$ by either method were judged to be urease-negative.

\section{Assay of cytotoxicity}

Cells of AGS (human gastric adenocarcinoma), Sf1Ep (cottontail rabbit epidermis) and HEp-2 (human larynx epidermoid carcinoma) cell lines obtained from the American Type Culture Collection were used in assays of cytotoxicity.

Cells were seeded into 24-well culture plates (Falcon) to produce a confluent monolayer after incubation for 2 days at $37^{\circ} \mathrm{C}$. Earle's Minimal Essential Medium (MEM; Flow) supplemented with non-essential amino acids and FCS $10 \%$ (FCS-MEM) was used for culture of SflEp and HEp-2 cells, and Ham's F12 medium (Flow) supplemented with FCS $10 \%$ (FCS-F12) for AGS cells. After incubation, the culture medium was removed, and two-fold dilutions of broth filtrates $(1 \mathrm{ml})$ in FCS-MEM or FCS-F12 were added to the wells followed by incubation at $37^{\circ} \mathrm{C}$ for $48 \mathrm{~h}$. Cells were observed at the indicated times by phase-contrast microscopy to determine cytotoxicity. The titre of cytotoxic activity was the highest final dilution of the sample that caused degenerative changes including intracellular vacuolation in more than $25 \%$ of the cells. FCS-YB broth alone was used as a negative control.

Ammonia water (ammonium hydroxide; $\mathrm{NH}_{3} \mathbf{2 8 \%}$ in water), ammonium chloride and ammonium sulphate were diluted in FCS-MEM and added to SflEp cells to determine their cytotoxicity. The cytotoxicities of several combinations of broth filtrates of CPY 4110 or CPY4111, jack bean urease, and urea were also evaluated.

\section{Observation of cytopathic effects}

For photomicrography, Sf1Ep cells treated under various conditions were washed twice with PBS, fixed with methanol and stained for $15 \mathrm{~min}$ by Giemsa.

\section{Determination of ammonia}

Ammonia concentrations in broth filtrates were determined by the method of Kitajima and coworkers. ${ }^{20}$

\section{Assay of urease activity}

Urease activity was quantified spectrophotometrically as described by Mobley and co-workers. ${ }^{21}$ Samples $(5-50 \mu \mathrm{l})$ were added to cuvettes $(1-\mathrm{cm}$ path length) containing $3 \mathrm{ml}$ of $3 \mathrm{~mm}$ sodium phosphate (pH 6.8), phenol red $7 \mu \mathrm{g} / \mathrm{ml}$ and $250 \mathrm{~mm}$ urea. Optical density at $560 \mathrm{~nm}$ was followed at $37^{\circ} \mathrm{C}$, and reaction rates were calculated from linear portions of the curves (0.15-0.5 OD) with ammonia water as a standard. One unit of the enzyme activity was defined as $1 \mu \mathrm{mol}$ of urea hydrolysed per min.

Table I. Cytotoxic activity in broth-culture filtrates of $H$. pylori for three epithelial cell lines

\begin{tabular}{l|rcr}
\hline \multirow{2}{*}{ Strain } & \multicolumn{3}{|c}{ Titre* of cytotoxic activity against } \\
\cline { 2 - 4 } & AGS & HEp-2 & Sf1Ep \\
\hline NCTC 11637 & 32 & 4 & 32 \\
CPY0103 & 4 & 2 & 16 \\
CPY0112 & 8 & 2 & 16 \\
CPY0163 & 16 & 1 & 8 \\
CPY0521 & 8 & 1 & 16 \\
CPY4110 & 8 & 1 & 4 \\
S2473 & 4 & 1 & 4 \\
V0031 & 8 & 2 & 16 \\
V0111 & 2 & 2 & 8 \\
& & & \\
\hline
\end{tabular}

* The highest dilution that caused degeneration, including intracellular vacuolation or cell detachment from culture plates, in more than $25 \%$ of the cells after incubation for $48 \mathrm{~h}$. 

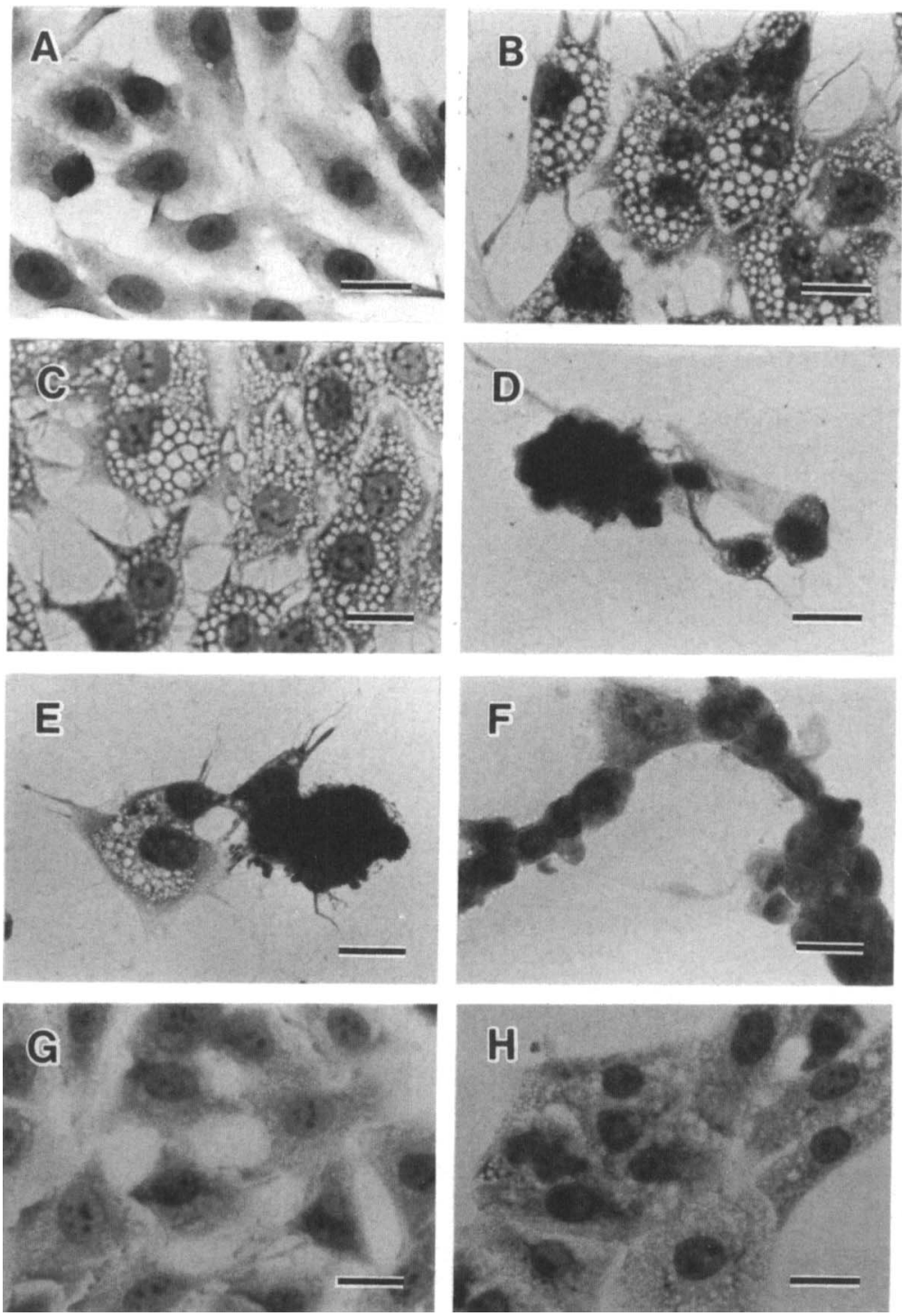

Figure. Giemsa-stained SfIEp cells incubated (A) in $1 \mathrm{ml}$ of FCS-YB broth for $6 \mathrm{~h}$; (B) $25 \%$ broth-culture filtrate of CPY4110 (wild-type) in MEM for $6 \mathrm{~h}$; (C) $25 \%$ broth-culture filtrate of CPY4111 (a urease-negative mutant) in MEM for $6 \mathrm{~h}$; (D) 15 mM ammonia in MEM for $10 \mathrm{~min}$; (E) $25 \%$ broth-culture filtrate of CPY 4110 with $30 \mathrm{mM}$ urea in MEM for $45 \mathrm{~min}$; (F) $30 \mathrm{~mm}$ urea and 0.1 unit of jack bean urease in MEM for $10 \mathrm{~min} ;(\mathbf{G}) 7.5 \mathrm{mM}$ ammonium chloride in MEM for $24 \mathrm{~h} ;(\mathrm{H}) 7.5 \mathrm{mM}$ ammonium chloride in MEM for $48 \mathrm{~h}$. Broth-culture filtrates of CPY4110 and CPY4111 were the same as described in table II. Bars, $20 \mu \mathrm{m}$.

\section{Results}

The cytotoxicity of nine strains of $H$. pylori for three mammalian cell lines was determined without addition of urea (table I). Broth filtrates of all the strains caused concentration-dependent degeneration of the cells with intracellular vacuolation, although the titre of cytotoxic activity varied between strains. AGS and Sf1Ep cells were more susceptible to damage than HEp-2 cells. FCS-YB broth alone did not produce such discernible CPEs on any of the cell lines after incubation for $48 \mathrm{~h}$.

When the broth filtrate of CPY 4110 was added to Sf 1 Ep cells, vacuolation appeared after $30 \mathrm{~min}$ and gradually increased (figure, B). The cells remained attached to the culture plates even after incubation for $48 \mathrm{~h}$.

To determine the role of cytotoxin production by $H$. pylori, urease-negative mutants were isolated after
NTG treatment. By screening 1580 clones, three urease-negative mutants were obtained. The biochemical characteristics of the mutants other than urease production were the same as those of the wildtype strain CPY4110. One of these, CPY4111, was used in subsequent experiments.

The broth filtrate of CPY4111 also showed a cytotoxic activity towards the three cell lines which was similar to that of CPY4110 both in titre and in morphology (figure, C).

To determine the role of ammonia in producing the CPEs observed, various concentrations of ammonia were added to Sf1Ep cells. No CPEs were seen with ammonia concentrations of less than $7.35 \mathrm{mM}$, even after $48 \mathrm{~h}$. When $14.7 \mathrm{~mm}$ ammonia was added, some cells became rounded within $10 \mathrm{~min}$ and subsequently became detached from the culture plates (figure, D). The typical vacuolation was not seen within the cells. Following the addition of $29.4 \mathrm{~mm}$ ammonia, almost 
Table II. CPEs produced by $H$. pylori culture filtrate on SflEp cells after incubation for 2 days

\begin{tabular}{lccr}
\hline & \multicolumn{2}{c}{$\begin{array}{c}\text { Titre* of cytotoxic activity } \\
\text { in the presence of }\end{array}$} \\
\cline { 2 - 4 } Test sample & no urea & 3 mM urea & 30 mM urea \\
& & & \\
Culture filtrate $\dagger$ of & 8 & 32 & 64 \\
CPY4110 alone & 8 & 8 & 8 \\
CPY4111 alone & $\ldots$ & $\ldots$ & 64 \\
CPY4111 and urease $\neq$ & 0 & 0 & 0 \\
Brucella broth alone & 0 & $\ldots$ & 64 \\
Brucella broth and & & & \\
urease & & &
\end{tabular}

* See legend for table I; 0, no CPE.

+ CPY4110 filtrate contained 0.098 unit of urease activity $/ \mathrm{ml}$, whereas CPY4111 filtrate had no activity.

$\ddagger$ Jack bean urease, $0 \cdot 1$ unit $/ \mathrm{ml}$.

$\ldots$, not determined.

all the cells showed such degeneration within $10 \mathrm{~min}$. Concentrations of ammonia in the broth filtrate of CPY4110 and its urease-negative derivative, CPY4111, were $16.5 \mathrm{~mm}$ and $14.0 \mathrm{~mm}$, respectively, whereas FCS-YB broth contained $3.5 \mathrm{~mm}$ ammonia. These results suggest that a large portion of ammonia in the broth filtrates is a urease-independent metabolic product of the bacteria.

The broth filtrate of strain CPY4110 contained urease activity of $0.098 \mathrm{unit} / \mathrm{ml}$, whereas no activity was detected in the broth filtrate of strain CPY4111. Therefore, it was expected that the broth filtrate of CPY4110 might produce CPEs due to ammonia produced from urea by the action of urease. In fact, when the broth filtrate of CPY4110 containing 0.025 units of urease was added to Sf1Ep cells in the presence of urea, intracellular vacuolation appeared within $30 \mathrm{~min}$, and the cells were gradually rounded up and detached from the culture plates after incubation for 45 min (figure, E). By this time the concentration of ammonia was estimated to have increased from $4.1 \mathrm{mM}$ to $6.4 \mathrm{~mm}$ by the action of urease. Addition of 0.1 unit of jack bean urease and $30 \mathrm{~mm}$ urea to FCS-MEM also caused CPEs on the cells with morphology similar to those by ammonia alone (figure, F).

Ammonium chloride or ammonium sulphate alone, at a concentration $>7.5 \mathrm{~mm}$, produced a different type of cytopathic effect. Very tiny vacuoles appeared in the cells within $30 \mathrm{~min}$ and increased in number (figure, $\mathrm{G}$ ), but remained small even after incubation for $48 \mathrm{~h}$ (figure, $\mathrm{H}$ ).

Titres of the cytotoxic activity of various combinations of the broth filtrate of wild-type strain CPY4110 or of mutant CPY4111, Brucella Broth, and jack bean urease, in the presence or absence of urea, are summarised in table II. Both of the broth filtrates produced a similar degree (titre 8) of CPE on Sf1Ep cells in the absence of urea. In the presence of $30 \mathrm{~mm}$ urea, the broth filtrate of strain CPY 4110 showed an increase in cytotoxic activity to a titre of 64 , whereas that of mutant CPY4111 did not display such an increase in the activity. In contrast, when the broth filtrate of the urease-negative mutant CPY4111 was supplemented with jack bean urease, the titre was the same as that of the broth filtrate of strain CPY 4110 . These results suggest that two factors, ammonia produced from urea by $H$. pylori urease and cytotoxic substance released from the organism, contribute to CPEs.

\section{Discussion}

Leunk et al. ${ }^{10}$ reported that $H$. pylori produced a protein other than urease that is responsible for CPEs. Subsequently, it has been reported that ammonia produced from urea by the urease of $H$. pylori causes CPEs. ${ }^{14,16,17}$ To clarify the importance of the cytotoxin and ammonia in $H$. pylori cytotoxicity in vitro, we produced a urease-negative mutant (CPY4111) of a clinical isolate of $H$. pylori (CPY4110).

We have shown in this study that the broth filtrates of each of the nine strains of $H$. pylori tested caused intracellular vacuolation. We have also shown that ammonia as well as urea and jack bean urease could induce rounding and detachment of the cultured cells without vacuolation, whereas ammonium salts induced the production of small vacuoles. Thus the morphological changes in the cells induced by these agents are distinct from those induced by the broth filtrates of $H$. pylori.

The broth filtrate of strain CPY4110 induced vacuolation followed by rounding and detachment of Sf1Ep cells in the presence of urea (figure, E). Although Leunk et al. ${ }^{10}$ did not measure urease activity in broth-culture filtrates of $H$. pylori, we demonstrated such activity in the broth filtrate of strain CPY4110. Therefore, the above findings indicate that urease hydrolysed urea to produce ammonia during incubation which then caused cell rounding and detachment. In fact, the broth filtrate of the ureasenegative mutant supplemented with jack bean urease induced a similar type and extent of cytotoxicity. It should be noted that the concentration of ammonia at the time the micrograph in figure, $\mathrm{E}$ was taken was estimated to be $6.4 \mathrm{mM}$, which was well below the concentration needed to produce CPEs in the absence of culture filtrate. Thus the cultured cells, having been induced to vacuolation by the cytotoxic substances, were more susceptible to urease-induced damage than those without vacuolation.

During the preparation of this manuscript, Cover $e t$ $a l .^{22}$ have reported findings similar to ours. They have suggested that the vacuolating activity of $H$. pylori supernatant is not mediated solely by urease activity but that it may be potentiated by urease-mediated ammonia production. They used a neutral red uptake method as a quantitative assay of cell vacuolation. We have demonstrated that the CPE induced by the cytotoxic substance is one of intracellular vacuolation, whereas that induced by ammonia is of rounding and detachment. As Leunk et al. ${ }^{11}$ suggested, intracellular 
vacuolation may be non-lethal, but further attack by ammonia may then lead to irreversible damage. Thus, both the cytotoxic substance and the urease of $H$. pylori contribute to lethal cytotoxicity in vitro. It is possible to speculate that such a mechanism operates in vivo also, during the development of peptic ulceration, since cytotoxin-producing stains of $H$. pylori

\section{References}

1. Goodwin CS, Armstrong JA, Chilvers T et al. Transfer of Campylobacter pylori and Campylobacter mustelae to Helicobacter gen. nov. as Helicobacter pylori comb. nov. and Helicobacter mustelae comb. nov., respectively. Int $J$ Syst Bacteriol 1989; 39: 397-405.

2. Blaser MJ. Helicobacter pylori and the pathogenesis of gastroduodenal inflammation. $J$ Infect Dis 1990; 161: 626-633.

3. Blaser MJ. Epidemiology and pathophysiology of Campylobacter pylori infections. Rev Infect Dis 1990; 12 Suppl 1: S99-S106.

4. Marshall BJ. Campylobacter pylori: its link to gastritis and peptic ulcer disease. Rev Infect Dis 1990; 12 Suppl 1: S87-S93.

5. Marshall BJ, Armstrong JA, McGechie DB, Glancy RJ. Attempt to fulfil Koch's postulates for pyloric campylobacter. Med J Aust 1985; 142: 436-439.

6. Morris A, Nicholson G. Ingestion of Campylobacter pyloridis causes gastritis and raised fasting gastric $\mathrm{pH} . \mathrm{Am} \mathrm{J}$ Gastroenterol 1987; 82: 192-199.

7. Chen XG, Correa P, Offerhaus $\mathrm{J}$ et al. Ultrastructure of the gastric mucosa harboring campylobacter-like organisms. Am J Clin Pathol 1986; 86: 575-582.

8. Fiocca R, Villani L, De Giacomo C et al. Morphological evidence of Campylobacter pylori pathogenicity in chronic gastritis and peptic ulcer. Acta Gastroenterol Belg 1989; 52 : 324-335.

9. Hupertz V, Czinn S. Demonstration of a cytotoxin from Campylobacter pylori. Eur J Clin Microbiol Infect Dis 1988; 7: $576-578$.

10. Leunk RD, Johnson PT, David BC, Kraft WG, Morgan DR. Cytotoxic activity in broth-culture filtrates of Campylobacter pylori. J Med Microbiol 1988; 26: 93-99.

11. Leunk RD, Ferguson MA, Morgan DR, Low DE, Simor AE. are isolated more frequently from patients with peptic ulcer than from patients with chronic gastritis alone. ${ }^{12}$ However, it should be noted that the local concentration of urea is another important factor that contributes to the pathogenicity of $H$. pylori.

This work was supported by Grants-in-Aid for Scientific Research from the Ministry of Education, Science, and Culture of Japan.
Antibody to cytotoxin in infection by Helicobacter pylori. $J$ Clin Microbiol 1990; 28: 1181-1184.

12. Figura N, Guglielmetti P, Rossolini A et al. Cytotoxin production by Campylobacter pylori strains isolated from patients with peptic ulcers and from patients with chronic gastritis only. J Clin Microbiol 1989; 27 : 225-226.

13. Cover TL, Dooley CP, Blaser MJ. Characterization of and human serologic response to proteins in Helicobacter pylori broth culture supernatants with vacuolizing cytotoxin activity. Infect Immun 1990; 58: 603-610.

14. Barer MR, Elliot TSJ, Berkeley D, Thomas JE, Eastham EJ. Cytopathic effects of Campylobacter pylori urease. J Clin Pathol 1988; 41 : 597 (letter).

15. Goodwin CS, Armstrong JA. Microbiological aspects of Helicobacter pylori (Campylobacter pylori). Eur J Clin Microbiol Infect Dis 1990; 9: 1-13.

16. Smoot DT, Mobley HLT, Chippendale GR, Lewison JF, Resau JH. Helicobacter pylori urease activity is toxic to human gastric epithelial cells. Infect Immun 1990; 58: 1992-1994.

17. Xu J, Goodwin CS, Cooper M, Robinson J. Intracellular vacuolisation caused by the urease of Helicobacter pylori. $J$ Infect Dis 1990; 161: 1302-1304.

18. Nakazawa $\mathrm{T}$, Ishibashi $\mathrm{M}$, Konishi $\mathrm{H}$ et al. Hemagglutination activity of Campylobacter pylori. Infect Immun 1989; 57 : 989-991.

19. Clowes RR, Hayes W. Experiments in microbial genetics. New York, John Wiley and Sons. 1968: 187

20. Kitajima K, Miyamura S. Direct determination of blood ammonia by Berthelot's coloration of protein-free supernatant obtained by Folin-Wu deproteinization. Bull Yamaguchi Med Sch 1968; 15: 207-217.

21. Mobley HLT, Cortesia MJ, Rosenthal LE, Jones BD. Characterization of urease from Campylobacter pylori.JClin Microbiol 1988; 26: 831-836.

22. Cover TL, Puryar W, Perez-Perez GI, Blaser MJ. Effect of urease on HeLa cell vacuolation induced by Helicobacter pylori cytotoxin. Infect Immun 1991; 59: 1264-1270. 